\title{
Mario Scognamiglio, Balzac editore. Una allucinante esperienza del grande scrittore
}

\section{Marco Stupazzoni}

\section{(2) OpenEdition}

1 Journals

\section{Edizione digitale}

URL: http://journals.openedition.org/studifrancesi/8969

DOI: $10.4000 /$ studifrancesi.8969

ISSN: 2421-5856

\section{Editore}

Rosenberg \& Sellier

\section{Edizione cartacea}

Data di pubblicazione: 1 octobre 2008

Paginazione: 472

ISSN: 0039-2944

\section{Notizia bibliografica digitale}

Marco Stupazzoni, «Mario Scognamiglio, Balzac editore. Una allucinante esperienza del grande scrittore», Studi Francesi [Online], 155 (LII | II) | 2008, online dal 30 novembre 2015, consultato il 12 janvier 2021. URL: http://journals.openedition.org/studifrancesi/8969; DOI: https://doi.org/10.4000/studifrancesi. 8969

Questo documento è stato generato automaticamente il 12 janvier 2021.

\section{(c) 9 (i) $\Theta$}

Studi Francesi è distribuita con Licenza Creative Commons Attribuzione - Non commerciale - Non opere derivate 4.0 Internazionale. 


\title{
Mario Scognamiglio, Balzac editore. Una allucinante esperienza del grande scrittore
}

\author{
Marco Stupazzoni
}

\section{NOTIZIA}

MARIO SCOGNAMIGLIO, Balzac editore. Una allucinante esperienza del grande scrittore, in La Bibbia del pope e altri scritti di bibliofilia, Milano, Edizioni Rovello, 2005 («I germogli de l'Esopo»), pp. 23-28.

1 In questo breve studio (pubblicato originariamente nella rivista «L'Esopo» del dicembre 1980), l'autore tratta dei fallimenti commerciali del giovane Balzac legati alle sue iniziative nel campo dell'editoria a partire dal 1826. L'insuccesso dell'Imprimerie de Honoré de Balzac fu immediato e irreversibile: soltanto grazie all'intervento finanziario di Mme de Berny, lo scrittore riuscì a tacitare i più accaniti creditori e a salvarsi dal carcere. L'autore riferendosi ad un capitolo contenuto nell'opera di R. Escholier, Logis romantiques (1930), ricostruisce l'ultima sera trascorsa da Balzac nella casa di rue de Marais, quando, grazie alla provvidenziale ed affettuosa presenza della sua Dilecta, il romanziere fu dissuaso dal gesto di togliersi la vita. 